\title{
The bat fauna of the Kararaô and Kararaô Novo caves in the area under the influence of the Belo Monte hydroelectric dam, in Pará, Brazil
}

\author{
Zortéa, M. ${ }^{a *}$, Bastos, $N A .^{b}$ and Acioli, TC. ${ }^{b}$ \\ aPrograma de Pós-Graduação em Biodiversidade Animal, Universidade Federal de Goiás, \\ Regional Jataí, Br. 364 Km 195, CEP 75801-615, Jataí, GO, Brazil

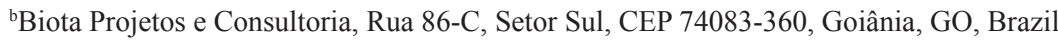 \\ *e-mail: mzortea@uol.com.br
}

Received: June 6, 2014 -Accepted: January 8, 2015 - Distributed: August 31, 2015

(With 2 figures)

\begin{abstract}
Brazil's large territory displays significant richness in caves with about 12 thousand caves already recorded. Nevertheless, studies on bats in these environments are extremely scarce and fragmented. This study characterized the chiropteran fauna from two sandstone caves under the influence of the Belo Monte hydroelectric dam (Belo Monte UHE) in Pará, Brazil. The Kararaô and Kararaô Novo caves are located on the same ridge, $250 \mathrm{~m}$ apart. Three expeditions were carried out in 2013 and 2014, with a 4- to 5-month interval in between. A total of 589 animals were caught, 246 in the Kararaô cave and 343 in the Kararaô Novo cave. Fifteen species were recorded (13 in each cave) representing 79\% similarity. With the exception of Vampyrum spectrum, which is not a cave species, the remaining recorded species were mostly cave bat species. Some species seemed to use the caves seasonally, although the basis of this pattern is still unknown. The most commonly observed species were Pteronotus personatus (dominant in the Kararao cave), P. parnellii (dominant in the Kararaô Novo cave), and Lionycteris spurrelli, which accounted for $65 \%$ of all captures recorded for the two caves. Natalus macrourus is a species recorded in the Kararao cave that is regionally threatened with extinction. Both caves are less than $500 \mathrm{~m}$ from the future reservoir; however, because the Kararaô cave entry is in an area that is lower than the reservoir, it can suffer alterations that would affect its dynamics. This raises great concern about the cave's associated fauna.
\end{abstract}

Keywords: biodiversity, caves, conservation, reservoir.

\section{A fauna de morcegos das cavernas Kararâ̂ e Kararaô Novo na área de influência da Usina Hidrelétrica de Belo Monte, Pará}

\section{Resumo}

O Brasil, com sua vasta porção territorial compreende uma alta riqueza de cavernas com cerca de 12 mil já registradas. Não obstante, os estudos sobre morcegos nestes ambientes são extremamente escassos e fragmentados. Neste estudo caracterizamos a quiropterofauna de duas cavernas areníticas sob influência da Usina Hidrelétrica de Belo Monte no Pará. As cavernas Kararaô e Kararâ Novo estão localizadas na mesma escarpa separadas por $250 \mathrm{~m}$ uma da outra. Foram realizadas três expedições com intervalo de 4 e 5 meses nos anos de 2013 e 2014. Realizou-se 589 capturas, sendo 246 na caverna Kararaô e 343 na Kararaô Novo. Quinze espécies foram registradas das quais duas foram exclusivas de cada caverna, equivalendo a $79 \%$ de similaridade. Excetuando-se o registro de Vampyrum spectrum, uma espécie não cavernícola, todas as demais são morcegos usualmente ou preferencialmente cavernícolas. Algumas espécies parecem usar sazonalmente as cavernas embora o porquê deste padrão seja ainda desconhecido. As espécies mais comumente observadas foram Pteronotus personatus (dominante na Kararaô), P. parnellii (dominante na Kararaô Novo) e Lionycteris spurrelli que totalizaram $65 \%$ das capturas somando-se os registros das duas cavernas. Uma espécie ameaçada regionalmente de extinção, Natalus macrourus, foi registrada na Kararaô. As duas cavernas estão a menos de 500 metros do futuro reservatório da UHE Belo Monte, porém, a entrada da caverna Kararaô está em uma cota mais baixa que a do limite do reservatório, podendo sofrer alteração em sua dinâmica, denotando maior preocupação em relação a sua fauna associada.

Palavras-chave: biodiversidade, cavernas, conservação, reservatório. 


\section{Introduction}

Fifteen percent of all bat fauna on the planet is in Brazil, and much of this richness is in the Amazon biome. A total of 146 species are recorded in this biome, distributed in nine families (Paglia et al., 2012). Of these, at least 46 species are endemic to the Amazon biome (Bernard et al., 2011a). Pará state hosts approximately 120 species and thus shows the greatest richness in Brazil (Bernard et al., 2011a).

Regardless of significant advances in knowledge about the diversity of Brazilian bats in the last two decades, few areas have been minimally sampled (Bernard et al., 2011b). Bats are not the only mammals inhabiting caves; however, they best exploit this type of environment, and some caves hold colonies with millions of individuals (Kunz, 1982). The caves are an important environment for several bat species, which, in turn, fundamentally contribute to the cave dynamics through an allochthonous supply of resources.

Studies of caves in Brazil are still scarce and fragmented, and few caves have been sufficiently sampled. According to Guimarães (2014), bat surveys and occasional records are reported in 266 out of the 12,000 caves in Brazil.

According to the CECAV database (2014), there are 1,819 caves recorded in Pará, of which 616 are recorded by the Brazilian Society of Speleology (SBE, 2014). The only information about bats and caves in the state of Pará is from studies by Trajano and Moreira (1991), Pinto-da-Rocha (1995), and Pinheiro et al. (2001), which demonstrate the critical lack of knowledge on cave fauna in Pará.

In the current study, we conducted a survey in two neighboring caves that make up the Kararaô complex, the Kararaô cave and Kararaô Novo cave, located in the area under direct influence of the Belo Monte hydroelectric dam.

This study contributes to the knowledge on the chiropteran fauna in caves in Pará and evaluates the potential environmental impact of the future Belo Monte hydroelectric reservoir on these animals' populations.

\section{Material and Methods}

The present study was carried out within the speleological province of Altamira-Itaituba, in two nearby caves, Kararaô and Kararaô Novo. These are to the left of the Santo Antônio Creek watershed, on the opposite ridge to the Santa Helena stream valley, in the municipality of Vitória do Xingu, and in the micro-region of Altamira, Brazil.

The Altamira-Itaituba Speleological Province is located in the contacting board of the geological domains of the Sedimentary Basin of the Amazon River and the Cristalino basement in the Xingu River Complex (Freire et al., 2013). The Kararaô and Kararaô Novo caves, as well as most of the caves in the Altamira region, are formed in shales from the Curuá Formation, showing development in friable sandstones from the Maecuru Formation (Norte Energia, 2009). These caves were mapped by a speleological team to comply with the environmental restrictions for the Belo Monte project (Norte Energia, 2009, 2010 - Technical Reports). The description of the two caves follows.
-(PA-022) Kararaô Cave (409117 L - 9652836 W): This cave is in a small mountain range with an approximate N-S orientation, corresponding to a residual relief associated with the occurrence of sandstones from the Maecuru Formation. Located in the area directly affected by the Belo Monte project, the cave is located at $178 \mathrm{~m}$ from the future reservoir (Leme Engenharia, 2009).

- Kararaô Novo Cave (408921 L - 9653076 W): This cave still does not have a registration number in the National Register of Caves (CECAV, 2014). The Kararaô Novo cave is in the same area of the Kararaô cave, however, it is on a stretch where the sandstone ridge shows an N-S inflection to NW. This cave has only one opening facing SW (Norte Energia, 2009). It is located in the area of direct influence of the Belo Monte project and is located at $474 \mathrm{~m}$ from the future reservoir.

In structural terms, the two caves are in the same sandstone ridge, however, they have distinguishing characteristics. The Kararaô cave is the largest and has ample lounges and a permanent stream. The Kararaô Novo cave is a dry cave, has a wide opening that becomes reduced, and has stacks of fallen rocks. The caves are $150 \mathrm{~m}$ apart in a straight line. The native vegetation around both caves is composed of rain forest very disturbed with the conversion of forests mainly in pastures. The remaining forest fragments present secondary state of growth.

Bat fauna in the two caves was sampled during three field expeditions. These expeditions were 2-3 days each and occurred in May (rainy season) and September (dry season) of 2013 and February (rainy season) of 2014. Two methods were employed to capture the bats: mist-nets and harp traps. Both methods were used when the bats first emerged from the caves, from 5:30 pm until 9:30 pm.

Four mist-nets were placed each day in the Kararaô Novo cave and two in the Kararaô cave. The nets measured 15 meters long by 3 meters high and were placed inside and at the cave openings. The effort with mist nets was calculated according to Straube and Bianconi (2002).

One single harp trap was used in alternating days in both caves. This type of trap is extremely useful in areas of high concentration of bats such as caves (Kunz and Kurta, 1988). The trap had a $1.50 \times 1.50 \mathrm{~m}$ interception frame and was placed $1 \mathrm{~m}$ above the ground. This trap was not available in the first expedition when the catches were performed only using the mist-nets. The sampling effort in each method is presented in Tables 1 and 2.

All traps were constantly inspected during the sampling period. Captured bats were packed in cloth bags and subsequently manipulated for the biometric measurements. The data collected from each specimen included several pieces of identifying information: taxonomical identification at the lowest possible level, sex, age, reproductive stage, forearm measurements, and weight. The animals were banded with colored cylindrical necklaces (Esbérard and Daemon, 1999) and released in the same collection sites. 
Table 1. List of species and number of captures in the Kararaô Cave.

\begin{tabular}{lcccc}
\hline \multicolumn{1}{c}{ Taxa } & & Expeditions & \multicolumn{2}{c}{ Total } \\
\cline { 2 - 4 } & $\mathbf{1}^{\text {st }}$ & $\mathbf{2}^{\text {nd }}$ & $\mathbf{3}^{\text {rd }}$ & 49 \\
Pteronotus personatus (Wagner, 1843) & 20 & 0 & 29 & 45 \\
Pteronotus parnellii (Gray, 1843) & 22 & 7 & 16 & 45 \\
Lionycteris spurrelli Thomas, 1913 & 0 & 36 & 9 & 40 \\
Anoura geoffroyi Gray, 1838 & 2 & 23 & 15 & 29 \\
Carollia perspicillata (Linnaeus, 1758) & 0 & 25 & 4 & 18 \\
Pteronotus gymnonotus (Wagner, 1843) & 6 & 1 & 11 & 6 \\
Natalus macrourus (Gervais, 1856) & 4 & 1 & 1 & 3 \\
Furipterus horrens (F. Cuvier, 1828) & 1 & 0 & 2 & 3 \\
Lonchorhina aurita Tomes, 1863 & 2 & 1 & 0 & 2 \\
Desmodus rotundus (E Geoffroy, 1810) & 0 & 1 & 1 & 2 \\
Diphylla ecaudata Spix, 1823 & 2 & 0 & 0 & 2 \\
Peropteryx trinitatis Miller, 1899 & 1 & 0 & 1 & 2 \\
Trachops cirrhosus (Spix, 1823) & 0 & 0 & 2 & 2 \\
Number of captures & 60 & 95 & 91 & 246 \\
Number of species & 9 & 8 & 11 & 13 \\
Harp Trap effort (hours) & 0 & 3 & 6 \\
Mist nets effort (m ${ }^{2}$ h) & 450 & 450 & 450 & 1350 \\
\hline
\end{tabular}

Table 2. List of species and number of captures in the Kararaô Novo Cave.

\begin{tabular}{|c|c|c|c|c|}
\hline \multirow{2}{*}{ Taxa } & \multicolumn{3}{|c|}{ Expeditions } & \multirow{2}{*}{ Total } \\
\hline & $1^{\text {st }}$ & $2^{\text {nd }}$ & $3^{\text {rd }}$ & \\
\hline Pteronotus parnellii (Gray, 1843) & 53 & 41 & 15 & 109 \\
\hline Pteronotus personatus (Wagner, 1843) & 58 & 3 & 36 & 97 \\
\hline Lionycteris spurrelli Thomas, 1913 & 2 & 23 & 11 & 36 \\
\hline Anoura geoffroyi Gray, 1838 & 17 & 0 & 13 & 30 \\
\hline Carollia perspicillata (Linnaeus, 1758) & 3 & 20 & 4 & 27 \\
\hline Pteronotus gymnonotus (Wagner, 1843) & 11 & 6 & 9 & 26 \\
\hline Peropteryx macrotis (Wagner, 1843) & 5 & 0 & 0 & 5 \\
\hline Lonchorhina aurita Tomes, 1863 & 0 & 4 & 0 & 4 \\
\hline Furipterus horrens (F. Cuvier, 1828) & 1 & 2 & 0 & 3 \\
\hline Desmodus rotundus (E. Geoffroy, 1810) & 1 & 0 & 1 & 2 \\
\hline Trachops cirrhosus (Spix, 1823) & 1 & 0 & 1 & 2 \\
\hline Diphylla ecaudata Spix, 1823 & 0 & 0 & 1 & 1 \\
\hline Vampyrum spectrum (Linnaeus, 1758) & 0 & 1 & 0 & 1 \\
\hline Number of captures & 152 & 100 & 91 & 343 \\
\hline Number of species & 10 & 8 & 11 & 13 \\
\hline Harp Trap effort (hours) & 0 & 6 & 6 & 12 \\
\hline Mist nets effort (m2h) & 450 & 450 & 450 & 1350 \\
\hline
\end{tabular}

Two recaptures from a previous study conducted by a consulting team (unpublished data) were considered because the data were available in their database. These bats were banded with an aluminum numbered ring on their forearm.

The bat species were classified in categories of cave use and of richness and abundance of bats in caves according to Arita (1993).

The sampling sufficiency was evaluated by rarefaction curve based on the sample effort. The total expected richness was calculated with the estimator Jackknife 1 (1000 randomizations) for each cave based on sampling nights. Vampyrum spectrum was excluded from this analysis because it is not a bat found in caves (see results and discussion).

The faunistic similarity was calculated for the two caves using the Jaccard coefficient of similarity.

Voucher specimens were deposited in the Biodiversity Animal Laboratory at the Federal University of Goiás, Jataí Regional (IBAMA license nº 251/2013).

\section{Results and Discussion}

Among 589 captures, 246 in the Kararaô cave and 343 in the Kararaô Novo cave (Tables 1 and 2), 584 bats were caught; five individuals were recaptured. Thirteen species 

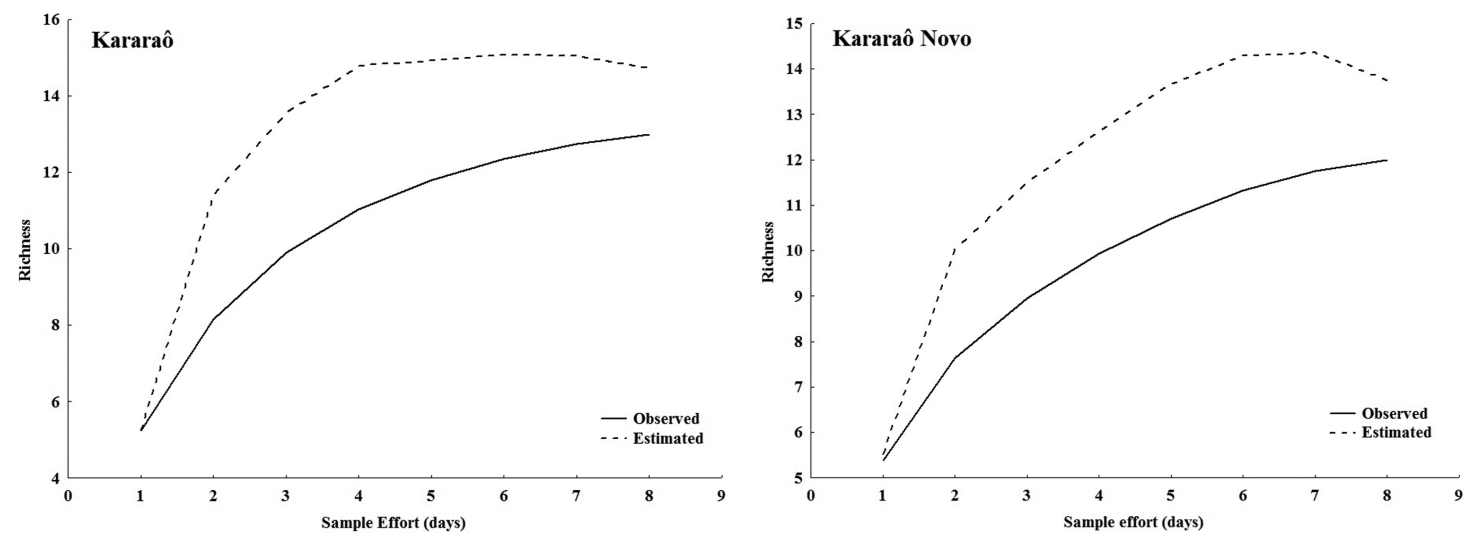

Figure 1. Mean values of observed and estimated species (Jackknife 1) of the Kararaô and Kararaô Novo caves.



Figure 2. Richness and abundance data for the bats recorded in the Kararaô and Kararaô Novo caves. The species Vampyrum spectrum was excluded from the analysis because it is not a cave species. The values in the graph represent the number of captures. Occasional use: bats that use caves occasionally; Preferential use: bats that use the cave as main roost.

were identified in each cave, of which two were exclusive in the Kararaô cave (Natalus macrourus and Peropteryx trinitatis), and two in the Kararaô Novo cave (Peropteryx macrotis and Vampyrum spectrum). In all, fifteen species were recorded from the two caves.

The cumulative curve of observed and expected species (Figure 1) showed that capture effort was not sufficient to include all species at the two caves. The Jackknife 1 estimated $14.75 \pm 1.5($ mean $\pm \mathrm{SD})$ species for Kararaô cave and $13.75 \pm 1.5$ species for Kararaô Novo. Thus, our observed richness included approximately $88 \%$ and $87 \%$ of the bat species expected for two caves.
Pteronotus personatus was the dominant species in the Kararaô cave, accounting for $19.9 \%$ of all captures, followed by $P$. parnellii and Lionycteris spurrelli with $18.3 \%$ each (Table 1). The same species were also the most common in the Kararaô Novo cave: Pteronotus parnellii (31.8\%), P. personatus (28.3\%), and L. spurrelli (10.5\%) (Table 2). These three species amounted to $65 \%$ of all captures in both caves.

Among all species caught, $V$. spectrum is the only species that does not inhabit caves, rather it shelters in hollow trees along watercourses (Navarro and Wilson, 1982). Its capture in the Kararaô Novo cave may have been the result of a foraging incursion as the species is carnivorous, occasionally feeding on other species of bats (Navarro and Wilson, 1982).

Peropteryx trinitatis is a species with few records in Brazil, with occurrences in the States of Bahia, Maranhão, and Pará (Hood and Gardner, 2008). The only record of this species in a cave was reported by Handley Junior (1976) in Venezuela. The present record is the first for caves in Brazil. This species can live in caves but also uses other types of shelters (Hood and Gardner, 2008).

Three recorded species, Carollia perspicillata, Desmodus rotundus, and Trachops cirrhosus use caves occasionally. The remaining recorded species are more dependent on caves.

The richness and abundance of species that use caves preferentially or occasionally (sensu Arita, 1993) were similar in the two caves (Figure 2).

According to Arita (1993) proposition on classification of richness and abundance of bats in caves, both the Kararaô and Kararaô Novo caves can be designated as highly rich (more than seven species), which shows the importance of these caves for the chiropteran fauna.

After the exclusion of $V$. spectrum, this study demonstrated $79 \%$ of faunistic similarity between the two caves. Although this similarity can be considered high, it should be noted that the two caves are separated by a few meters and located on the same ridge. The faunal complementarity observed indicates that the protection of a set of shelters (caves) would result in maintaining a higher biodiversity. 
Five recaptures of five different species occurred in this study. Four recaptures occurred in the Kararao cave between intervals of 13 to 20 months: Carollia perspicillata and Diphylla ecaudata (13 months); Anoura geoffroyi (14 months), and Lionycteris spurrelli (20 months). Pteronotus personatus was the only recaptured case in the Kararaô Novo cave, 5 months after its capture.

Two distinct seasonality patterns were observed in the caves (Tables 1 and 2):

Most abundant species in the rainy season: This pattern was observed in the three species of Pteronotus in both caves (except $P$. parnellii in the Kararaô Novo cave).

Most abundant species in the dry season: This pattern was observed for Carollia perspicillata and Lionycteris spurrelli. These species' population declined in the wet season in both caves.

Anoura geoffroyi was most captured in the dry season in the Kararaô cave. However, this species was most commonly recorded in the rainy season in the Kararaô Novo cave.

The seasonal use of caves by bats has been observed in temperate regions such as the United States (Kunz, 1982). However, according to this author, caves in tropical regions are environmentally more stable, and more uniform use of caves throughout the year should be observed. The seasonal pattern observed in some species in this study indicates that even in more stable environments, other factors may be influencing the dynamics of cave occupation.

All species recorded in this study have already been noted to occur in the state of Pará (Bernard et al., 2011a). However, the occurrence of Peropteryx trinitatis is worthy of note. The only citation of this species in Pará, collected in the city of Belém, comes from a compilation by Hood and Gardner (2008). These authors make reference to the locality "Utinga," which probably corresponds to the Environmental Park of Utinga, located around the State capitol.

According to Guimarães (2014), bats have been recorded in 13 of the 1,819 caves of the Pará State. This means that only $0.7 \%$ of caves in Pará have some citation regarding chiropteran fauna. In addition to the number of sampled caves being extremely low, these studies often only superficially mention the occurrence of bats in caves.

None of the species recorded in both caves is in the lists of endangered species on a global scale (IUCN, 2014), nor are they threatened in Brazil (Brasil, 2003). However, on a regional scale, Natalus espiritosantensis (=Natalus macrourus) is listed as "vulnerable" on the list of endangered species in the state of Pará (Pará, 2008).

According to speleological studies about the relevance of natural caves under the influence of the Belo Monte UHE (Norte Energia, 2010) and the current Brazilian legislation (Brasil, 2008, 2009), the Kararaô Cave was considered of utmost importance, whereas the Kararaô Novo Cave was considered highly relevant. The occurrence of one species threatened with extinction in the Kararaô cave (N. macrourus), and the high richness and abundance of bats in both caves reinforce the environmental relevance of these caves.

The Kararaô cave is located $178 \mathrm{~m}$ from of the limit of the future UHE dam. However, the cave entrance is at a level below the reservoir and may have its dynamics changed as a result of the implementation of the project. Monitoring the filling of the reservoir will be important to minimize possible impacts caused by the Belo Monte UHE.

\section{Acknowledgements}

We are grateful to the staff of the Norte Energia S.A. and Biota Projetos e Consultoria for financial support. We thank the collaborators: Tiago G. Junqueira, Débora Magnavita, Vanessa Lessa, Sérgio Barbieri, Josué L. S. Ricardo, Enéas F. Júnior, Ricardo C. Vital and Felipe S. M. Zenha for field assistance. We thank Christine V. Portfors for reviewing the final version of the manuscript.

\section{References}

ARITA, HT., 1993. Conservation biology of the caves bats of México. Journal of Mammalogy, vol. 74, no. 3, p. 693-702. http:// dx.doi.org/10.2307/1382291.

BERNARD, E., TAVARES, VC. and SAMPAIO, E., $2011 \mathrm{a}$. Updated compilation of bat species (Chiroptera) for the Brazilian Amazonia. Biota Neotropica, vol. 11, no. 1, p. 35-46. Available from: $<$ http://www.biotaneotropica.org.br/v11n1/en/abstract?art icle+bn00611012011>. Access in: 12 Apr. 2014

BERNARD, E., AGUIAR, LMS. and MACHADO, RB., 2011 b. Discovering the Brazilian bat fauna: a task for two centuries? Mammal Review, vol. 41, no. 1, p. 23-39. http://dx.doi. org/10.1111/j.1365-2907.2010.00164.x

Brasil. Ministério do Meio Ambiente-MMA, 2003. Lista Oficial das Espécies da Fauna Brasileira Ameaçadas de Extinção. Instrução Normativa $n^{\circ}$ 3, de 27 de maio de 2003. Diário Oficial da República Federativa do Brasil, Brasília. Seção vol. 1, no. 101, p. 88-97.

Brasil. Ministério do Meio Ambiente - MMA, 2008. Decreto $n^{\circ}$ 6.640, de 07 de novembro de 2008. Diário Oficial da República Federativa do Brasil, Brasília. Available from: <http://www. planalto.gov.br/ccivil_03/_Ato2007-2010/2008/Decreto/D6640. $\mathrm{htm}>$. Access in: 12 Apr. 2014.

Brasil. Ministério do Meio Ambiente - MMA, 2009. Instrução Normativa MMA $n^{\circ}$ 002, de 20 de agosto de 2009. Diário Oficial da República Federativa do Brasil, Brasília. Available from: $<$ http://www.icmbio.gov.br/cecav/images/download/IN\%20 02_MMA_criterios_210809.pdf>. Access in: 12 Apr. 2014.

Centro Nacional de Pesquisa e Conservação de Cavernas - CECAV, 2014. Base de dados geoespacializados das cavernas do Brasil. Available from: <http://www.icmbio.gov.br/cecav/downloads/ mapas $>$. Access in: 12 Apr. 2014

ESBÉRARD, CEL. and DAEMON, C., 1999. Novo método para marcação de morcegos. Chiroptera Neotropical, vol. 5, no. 1-2, p. 116-117. 
FREIRE, LC., LIMA, JS., SILVA, EV.,VERÍSSIMO, CUV. and PINHEIRO, RVL., 2013. Estudo da paisagem em patrimônios espeleológicos: considerações sobre o carste não-carbonático da província espeleológica Altamira-Itaituba (Pa). In Anais do $13^{\circ}$ Simpósio de Geologia da Amazônia, 2013. Belém. Belém: SBG. Available from: <http://13sga.sbg-no.org.br/index. php?option $=$ com_content $\&$ view $=$ article $\&$ id $=31 \&$ Itemid $=37>$. Access in: 12 Apr. 2014.

GUIMARÃES, MM. 2014. Morcegos cavernicolas do Brasil: composição, distribuição e serviços ambientais. Lavras: Universidade Federal de Lavras. 123 p. Masters Dissertation in Applied Ecology.

HANDLEY JUNIOR, CO., 1976. Mammals of the Smithsonian Venezuelan Project. Brigham Young University Science Bulletin - Biological Series, vol. 20, no. 5, p. 1-89.

HOOD, C. and GARDNER, AL., 2008. Family Emballonuridae. In GARDNER, AL. (Ed.). Mammals of South America. Chicago: The University of Chicago Press.

International Union for Conservation of Nature and Natural Resources - IUCN, 2014. IUCN Red List of Threatened Species. Version 2014.2. Available from: <http://www.iucnredlist.org>. Access in: 12 July 2014.

Leme Engenharia, 2009. Estudo de impacto ambiental do AHE Belo Monte. Diagnóstico da ADA e AID, meio biótico - ecossistema terrestre-fauna. Belo Horizonte: Leme Engenharia. p. 793-913.

KUNZ, TH. and KURTA, A., 1988. Capture methods and holding devices. In KUNZ, TH. (Ed.). Ecology and behavioral methods for the study of bats. Washington: Smithsonian Institution Press. p. 1-30.

KUNZ, TH., 1982. Roosting ecology of bats. In KUNZ, TH. (Ed.). Ecology of bats. New York: Plenum Press. vol. 18, p. 1-55.. http://dx.doi.org/10.1007/978-1-4613-3421-7_1.

NAVARRO, D. and WILSON, D., 1982. Vampyrum spectrum. Mammalian Species, no. 184, p. 1-4.
Norte Energia, 2009. Estudo de impacto ambiental do aproveitamento hidrelétrico Belo Monte. Brasília: Norte Energia. Technical Report.

Norte Energia, 2010. Usina hidrelétrica de Belo Monte: Estudos espeleológicos - estudo complementar. Brasília: Norte Energia. Technical Report.

Pará. Governo do Estado. Secretaria de Estado de Meio Ambiente e Sustentabilidade-SEMA, 2008. Resolução 054/2007. Lista das espécies ameaçadas de extinção do Pará. Available from: <http:// www.sema.pa.gov.br/2009/03/27/9439/>. Access in: 17 Apr. 2014.

PAGLIA, AP., FONSECA, GAB., RYLANDS, AB., HERRMAN, G., AGUIAR, LMS., CHIARELLO, AG., LEITE, YLR., COSTA, LP., SICILIANO, S., KIERULFF, MCM., MENDES, SL., TAVARES, VC., MITTERMEIER, RA., and PATTON, JL., 2012. Lista anotada dos mamiferos do Brasil. 2nd ed. Belo Horizonte: Conservação Internacional. 82 p. Occasional Paper, no. 6.

PINHEIRO, RVL., MAURITT, CW., HENRIQUES, AL., SILVEIRA, LT., MAREIRA, JRA., LOPES, PRC., SILVEIRA, OT., PAIVA, RS., LINS, ALFA., VERÍSSIMO, CUV., ARCANJO, SHS., KERN, DC., KRAUSE, EA., LIMA FILHO, MF., ROCHA, JB., SANTOS, W., 2001. As grutas bauxíticas da Serra do PiraíPA. Belém: Museu Paraense Emílio Goeldi. p. 65-97. Boletim do Museu Paraense Emílio Goeldi, Série Ciências da Terra, no. 13.

ROCHA, RP., 1995. Sinopse da fauna cavernícola do Brasil. Papéis Avulsos Zoologia (São Paulo), vol. 39, no. 6, p. 61-173.

Sociedade Brasileira de Espeleologia - SBE, 2014. As maiores cavernas do Brasil. Available from: <http://www.sbe.com.br/ cavernas_maiores.asp?txtestado=PA>. Access in: 20 May 2014.

STRAUBE, FC. and BIANCONI, GV., 2002. Sobre a grandeza e a unidade utilizada para estimar esforço de captura com utilização de redes-de-neblina. Chiroptera Neotropical, vol. 8, no. 1-2, p. 150-152.

TRAJANO, E. and MOREIRA, JRA., 1991. Estudo da fauna de cavernas da Província Espeleológica Arenítica Altamira-Itaituba. Brazilian Journal of Biology, vol. 51, no. 1, p. 13-29. 